\title{
Ekolojik Kriz Karşısında Devletin Rolü Üzerine İdeolojik Bir Tartışma
}

An Ideological Discussion on the Role of the State on the Ecological Crisis

\section{Duygu TAN GÜLCAN}

Dr., Sosyal Çevre Bilimleri Anabilim Dalı, Ankara Üniversitesi

\section{Bu makaleye atıf için}

Tan Gülcan, Duygu, "Ekolojik Kriz Karşısında Devletin Rolü Üzerine İdeolojik Bir Tartışma", Uluslararası İiş̧kiler, Cilt 13, Say1 59, 2018, s. 49-63, DOI: 10.33458/uidergisi.523829

Makaleye Erişim İçin: https://dx.doi.org/10.33458/uidergisi.523829

Makale Gönderim: 05 Ocak 2017

Basım Tarihi: 01 Eylül 2018

\section{Uluslararası İlişkiler Konseyi Derneği | Uluslararası İlişkiler E-Posta: bilgi@uidergisi.com.tr}

Bu makalenin tüm hakları Uluslararası İişkiler Konseyi Derneğìne aittir. Önceden yazılı izin almadan hiçbir iletişim, kopyalama ya da yayın sistemi kullanılarak yeniden yayımlanamaz, çoğaltılamaz, dağıtılamaz, satılamaz veya herhangi bir ssekilde kamunun ücretli/ücretsiz kullanımına sunulamaz. Akademik amaçlı alıntılar bu kuralın dışındadır. Yazıda belirtilen fikirler yalnızca yazarına/yazarlarına aittir. UİK Derneğini, editörleri ve diğer yazarları bağlamaz. 


\title{
Ekolojik Kriz Karşısında Devletin Rolü Üzerine İdeolojik Bir Tartışma
}

\author{
Duygu TAN GÜLCAN \\ Dr., Sosyal Çevre Bilimleri Anabilim Dalı, Ankara Üniversitesi, Ankara. \\ E-Posta: duygu.tan.mail@gmail.com
}

Bu makale yazarm 2016 yılında Ankara Üniversitesi Sosyal Bilimler Enstitüsü’nde hazırladığı "Ekolojik Kriz ve Özel Mülkiyet, Eko-Liberal Özel Mülkiyet Savunusunun Marksist Eleştirisi” başlıklı doktora tezinden üretilmiştir.

\begin{abstract}
ÖZET
Karşı karşıya olduğumuz ekolojik kriz on yıllar içerisinde yaşam koşullarımızı son derece sert bir biçimde etkileyebilecek boyutlara ulaşmıştır. Öyle ki içinde bulunduğumuz çağın, böyle büyük bir gezegensel dönüşüme sebep olan türümüzün isminin verilerek Antroposen olarak adlandırılması bile önerilmiştir. Yaşanılan ekolojik krizin boyutlarının gün geçtikçe ağırlaşması, devletin ekolojik kriz karşısındaki konumunu gündeme taşımaktadır. Hobbes'un güçlü devletine karşı Locke'un sınırlı devlet düşüncesi, devletin rolüne ilişkin ekolojik tartışmalarda önemli felsefi kaynaklardır. Öte yandan ekolojik kriz karşısında devletin atıl ve gerekli hamleleri yapmada isteksiz kalması, devletin gerçek fonksiyonunun doğru biçimde değerlendirilemediğine işaret eder. Bu çalışma, yeşil siyasal düşüncede yer alan tartı̧̧malar ekseninde, devletin ekolojik sorunlar karşısındaki konumunu belirginleştirmeyi amaçlarken, liberal devletin başarısız olmaya mahkum olduğunu savunmaktadır.
\end{abstract}

Anahtar Kelimeler: Ekolojik Kriz, Toplumsal Sözleşme Kuramı, Devlet, Yeşil Siyasal Düşünce, Eko-Marksizm

\section{An Ideological Discussion on the Role of the State on the Ecological Crisis}

\begin{abstract}
The ecological crisis that we face has reached to magnitudes which in the next decade can severely affect our conditions of life. So much that even the era we live in, is proposed to be called Anthropocene after the name of our species caused such a great planetary transformation. The daily increasing severity of the ecological crisis, has brought forward the importance of the role of state confronting the ecologic crisis. Hobbes' strong state versus Locke's limited state ideas are the fundamental philosophical sources on ecological discussions about role of the state. On the other hand, passiveness and reluctance of the state to take required actions against the ecological crisis indicates that the real function of the state is not being considered right. This study aims to clarify the position of the state in relation to ecological problems on the axis of green political thought and argues that the liberal state is doomed to fail in the face of the ecological crisis.
\end{abstract}

Keywords: Ecological Crisis, Social Contract Theory, State, Green Political Thought, Eco-Marxism 


\section{Giriş}

İnsan eylemlerinin doğal süreçler ve yerküre üzerinde yarattığı dönüşümler o kadar büyük boyutlara ulaşmıştır ki, insan etkisi gezegen tarihinde yaşanan beş büyük yok oluş ile kıyaslanan bir güç olarak görülmeye başlanmıştır. Gezegensel kırılmalar her geçen gün büyümekte, ekosistemlerin taşıma kapasiteleri sınırlara yaklaşmaktadır. Gezegende yer alan ve yaşamı mümkün kılan sistemler daha fazla fosil yakıt tüketimini veya ormanlık alanların yok oluşunu kaldıramaz duruma gelmiştir. Su, azot ve fosfor döngüleri başta olmak üzere, yeryüzündeki dengeleri koruyan sistemler eşik limitlerde seyretmektedir. Toprak kullanımı beşeri amaçlar uğruna tarımsal ve kentsel alanlar için işgal edildikçe, diğer türlerin yaşama imkânları gittikçe daralmaktadır. İklim değişimi, okyanus asitlenmesi, atmosferik aerosol yüklenmesi gibi sorunlar, birbirlerini tetikleyen bir biçimde gezegensel dengelerin bozulduğunu göstermektedir.

Öte yandan bugüne kadar alınan önlemlerin, çevre sorunlarını çözmede yetersiz kaldığı görülmektedir. Bu durum devletin ekolojik kriz karşısındaki rolünün önemini gündeme getirdiği gibi devletin gerekli hamleleri yapmadaki isteksiz tavrını da ortaya koymaktadır. Bu çalışmanın amacı, devletin ortaya çıkışı ve temel fonksiyonlarına ilişkin toplum sözleşmesi kuramcılarının görüşlerinden yola çıkılarak, devletin ekolojik kriz karşısındaki konumlanışını incelemektedir. Çalışma bahsi geçen kriz karşısında devletin edilgen tutumunun nedenlerini sorgulamaktadır. Bunun yanında devletin ekolojik sorunlara yönelik fonksiyonunun ne olması gerektiği yeşil siyasal düşünce çerçevesinde tartışılmaktadır.

\section{Savaş ve Barış}

Toplumsal düzenin, geçmişte var olan doğa durumunun engellenemez şekilde dönüşümü sonucu ortaya çıktığı toplumsal sözleşme kuramcılarının ortak söylemidir. Bugünkü kurumların ortaya çıkışını, "doğa durumu" olarak niteledikleri insanlığın en yalın, gelişmemiş halini inceleyerek ortaya koymaya çalışan bu kuramlar, bugünkü toplumsal yapının ne tür ihtiyaç ve baskılar sonucu oluşmuş olduğunu açıklamaya çalışırlar. Birbirlerinden farklı sonuçlara ulaşan sözleşme kuramcılarının ortak kanısı, insanlık tarihindeki bir takım gelişmeler sonucu doğa durumunun sürdürülemez şekilde bozulduğu ve yeni bir düzenin kurulmasını mutlak bir biçimde gerektirdiğidir. Bu noktadan sonra doğa durumunu sonlandıran bir sözleşmeyle yeni düzen, toplumsal durum inşa edilir. ${ }^{1}$

Thomas Hobbes, doğa durumunu sürekli bir savaş durumu olarak resmeder. Doğanın insanı içine soktuğu korunmasız durum, bireylerde birbirlerine karşı güvensizlik ve rekabet hisleri uyandırır. Bireyler, diğer bireylere ve hatta kendi aile fertlerine dahi güvensizlik besler. Güvensizlik hissi engellenemez şekilde güç kullanma arzusu ve savaş durumunu doğurur. Herkesin birbirinden şüphe duyduğu, gücü yeteni egemenliği altına almak arzusu uyandıran bu savaş durumu, medeniyete ve hatta yaşama dair gerçekleştirilecek herhangi bir eylemi gereksiz kılar. Hobbes'un doğa durumu, insanın kendi dışındaki tüm dünyadan şüphe edip korktuğu ve kendi canı da dâhil olmak üzere sahip olduğu, her şeyi kaybetme korkusuyla hareket ettiği bir durumdur. ${ }^{2}$ Bireyler arasındaki uzlaşmazlıkların temel nedeni aynı anda aynı şeyi elde etme arzularıdır. Herkes, elinde bulundurduğu şeye yalnızca elinde

1 Yıldız Silier, Özgürlük Yalınsaması Marx ve Rousseau, İstanbul, Yordam Kitap, 2010, s.48.

2 Thomas Hobbes, Leviathan veya Bir Din ve Dünya Devletinin İçeriği, Biçimi ve Kudreti, İstanbul, Yapı Kredi Yayınları, 2014, s.101. 
tutabildiği sürece sahiptir. Bölüşülemeyen şeye kimin sahip olacağına güçlü olan karar verir. Güçlü olanın kim olduğu ise mücadele ile belirlenir. Herkesin gücü ve iradesinin ötesinde egemen bir gücün varlığı söz konusu olmadıkça, doğa durumu bir savaş durumundan başka bir şey olamaz. ${ }^{3}$

Diğer bir sözleşmeci olan John Locke'ta doğa durumu başlangıçta bir savaş durumu değildir. ${ }^{4}$ Locke'un doğa durumu eşitlik ve özgürlük kavramlarıyla özdeşleştirilen, barışçl bir durumdur. Bireyler eylemlerini diledikleri gibi düzenleme ve mülkleriyle uygun gördükleri tasarrufta bulunma özgürlügüne sahiptir. Bunun yanında, eşit bireylerdir ve birbirleri arasında herhangi bir egemenlik bağı bulunmaz. İnsanların eşit ve özgür bir biçimde yaşamalarını olanaklı kılan ve bu noktada Locke'un doğa durumunu Hobbes'un savaş durumundan ayıran temel fark doğa yasalarıdır. Locke tüm bireylerin doğa yasalarıyla sınırlı olduğunu varsayar. Doğa yasalarını ihlal edenler istisnalardır ve varlıkları doğa durumunda süregelen barış haline zarar vermez. Barışın hâkim olduğu doğa durumunda dengelerin bozulması ve bunun sonucunda bir toplumsal duruma geçişin zorunluluğu, uygarlık seviyesinin yükselmesi ve paranın bulunmasıyla kendini gösterir. O zamana kadar kendine yeterli miktarla yaşayan birey için birikim mümkün olduğu andan itibaren huzur ortadan kalkar ve insanlar daha fazlasını istemeye başlar. Bireylerin büyük bölümü doğa yasalarına uyma eğilimden vazgeçer. Birikim nedeniyle bireyler arasındaki eşitlik bozulur ve bu eşitsizlik engellenemez bir biçimde Hobbes' unkine benzer bir savaş durumunu yaratır. ${ }^{5} \mathrm{Bu}$ savaş durumunda bireylerin (yaşama, sağlık, özgürlük ve sahiplenme haklarını da içeren geniş anlamda) mülkiyet hakları olsa da, bu hakları kullanabilecekleri olanakları kısıtlı ve sürekli tehdit altındadır. ${ }^{6}$

Jean Jacques Rousseau ${ }^{7}$ ise doğa durumunu, sınırlı yetenek ve isteklerle donanmış bireylerin yaşadığı ilkel bir dönem olarak tanımlar. Bireyler, yalnızca yaşamlarını sürdürmek için gerekli olan temel ihtiyaçlarını gidermek isterler. İnsan ihtiyaçları sınırlı olduğu için kaynak bolluğu vardır ve bu nedenle Hobbes'un doğal savaş durumuna benzer bir durum söz konusu değildir. İnsan gelişmemiş bir varlıktır ve ihtiyaçlarını karşılayabildiği için mutludur. Ancak insan aklının gelişmesi, bununla beraber ihtiyaçlarının artması ve çeşitlenmesi Rousseau'nun mutlu doğa durumunu bozar. Arzular ve ihtiyaçların çeşitlenmesi, bireylerin artık kendi kendilerine yetememesine ve sonuçta da ortaklaşa ürünler ortaya koymaya başladıkları bir durumu doğurur. Böylece birikim ortaya çıar ve eşitlik kaybolur. Mülkiyetin ortaya çıkması beraberinde eşitsizliği getirdiği için huzurlu doğa durumu sonsuza dek kaybolur.

Doğa durumu, her ne kadar kurgusal olsa da, tarihsel anlamda sanayileşme ve ekolojik kriz öncesi bir dönemi ifade eder. Doğa durumu kavramlaştırmasında, üç düşünür için de farklı anlamlar bulmak mümkündür. Hobbes'un yorumunda doğa durumundan kaçış, zor, acılı ve kısa bir yaşamın tek alternatifidir. Aydınlanmacı vahşi doğa kavrayışını andırarak Baconvari bir doğa durumu kurgusu yaratır. Doğa durumu insana ve insani olana uzak, medeni yaşam için elverişsizdir. Descartes'ın insan doğa ikiliğini Hobbes'un "doğa durumu” ve "toplum durumu” tezatllğında görmek mümkündür. ${ }^{8}$

3 Ibid, s.103, Thomas Hobbes, Elementa Philosophica De Cive Yurttaşlik Felsefesinin Temelleri, İstanbul, Belge Yayınları, 2014, s.27.

4 John Locke, Yönetim Üzerine İkinci İnceleme, Ankara, Ebabil Yayınları, 2012, s.10-12.

5 Fahri Bakırcı, John Locke'ta Mülkiyet Anlayışı, Ankara, Babil Yayınları, 2004, s.44- 45.

6 Locke, Yönetim Üzerine İkinci İnceleme, s.81.

7 Jean J. Rousseau, Toplum Sözleşmesi, İstanbul, Öteki Yayınevi, 2007, s.33- 39.

8 John M. Meyer, Political Nature, Londra, The MIT Press, 2001, s.62; René Descartes, “Nonhumans as Machine”, D. R. Keller (der), Environmental Ethics, the Big Question, West Sussex, Wiley- Blackwell Publ., s.71. 
Diğer taraftan Locke’taki doğa-toplum durumu ikiliği Hobbes'taki kadar birbirine zit bir biçimde kutuplaştırılmaz. Doğa durumunun ilk dönemleri barış ve huzur ile ilişkilendirilirken, doğa olumsuz bir öğe barındırmaz. Tersine doğa durumunu yaşanmaz kılan, servet birikimini mümkün kılan beşeri gelişim ve bunun sonucunda eşitsizliğin ortaya çıkışıdır.9

Toplum sözleşmesi kuramcılarına göre insanların sahip oldukları hak ve özgürlükleri kullanmalarını imkânsızlaştıran doğa durumunun sonlandırılması bir zorunluluk, bir kaçınılmazlık olarak belirmektedir. Toplumsal durum, kaotik ve kuralsız doğa durumunu tamamıyla sonlandıracak, bireylerin güven içinde yaşama ortamlarını oluşturacak bir durumdur. Bu durumda kişilerin her türlü saldırı ve tecavüze karşı endişe etmelerini gerektirecek bir tehlike yoktur. Yurttaşlar hak ve özgürlüklerinin bir kısmından vazgeçmeyi ve karşılığında bir otoritenin koyduğu kurallar ve uyguladığı yaptırımların sınırlaması içinde yaşamayı kabul ederler. Böylelikle, yaşamları ve mülkleri devletin koruması altına alınmış olur. ${ }^{10}$

Her ne kadar Hobbes ve Locke'un görüşleri bu noktaya kadar birbirine yakın bir seyir izlemiş olsa da, geliştirdikleri düşüncelerin günümüze yansıyan sonuçları birbirinden çok farklı hatta belki de karşıt olarak nitelenebilir. Savaş durumuna müdahale edip bireysel özgürlükleri sınırlayacak bir devlete ihtiyaç duyulduğu tartışmasızdır, ancak devletin sınırları meselesi Hobbes ile Locke'u karşı karşıya getirir. Hobbes güçlü bir yönetimi devletin başında görmekten memnundur oysa Locke'çu anlayış güçlü bir yönetimin bireysel özgürlükler önünde engel teşkil edeceğini savunur. Devlet olabildiğince küçük olmalı ve bireylerin kendi hayatlarına ve geleceklerine yönelik kararlarına izin vermelidir. Devletin görev tanımının genişlemesi, insanlara zulüm eden ve onları köleleştiren bir yönetim riskini doğurur. Devletin görev tanımı ne kadar geniş olursa, kaçınılmaz olarak bireysel özgürlükler de o denli zayıflayacaktır.

Sınırlı devlet anlayışı günümüz politikalarına yansıdığı ölçüde ekolojik sorunlar karşısındaki konumlanışta da kendini gösterir. Liberaller devletin sorunların çözümüne karışmaması, yalnızca gerekli düzenlemeleri gerçekleştirip gerisini piyasa koşullarına bırakması gerektiğini savunur. $\mathrm{Bu}$ görüşe göre serbest piyasa koşulları ihtiyaca cevap verecek şekilde sorunların kendiliğinden çözülmesini sağlayacaktır. ${ }^{11}$ Eko-vergiler, kirleten öder prensibi, çevre dostu üretimin devlet eliyle teşviki gibi mekanizmalarla devletin insanları daha yeşil bir yaşam tarzı benimsemeye teşvik edebileceği yönünde görüşler, devletin düzenleyici işlev üstlenmemesi gerektiği biçimindeki liberal tezlerle eleştirilir. Jong ${ }^{12}$, devletin piyasada yer almaması gerektiğini ancak düzenleyici bir rol üstlenmesi gerektiğini savunur. Örneğin, devlet rüzgâr tribünleri kurmamalıdır ancak kirli elektriğe yapılan sübvansiyonları kaldırmalıdır. Bu şekilde şirketler kendiliğinden rüzgâr tribünleri kurma yoluna gidecektir. Devletin bahsedilen düzenleyici rolü taşımacılık, organik tarım, ucuz konutlar, enerji tüketiminin azaltılması ve artan şehirleşmenin önlenmesi gibi pek çok alanda etkili bir çözüm sunabilecektir. Piyasa gerçek maliyetleri yansıttığında ise devletin düzenleme mekanizması devreden çıkabilecektir.

9 Bakırcı, John Locke'ta Mülkiyet Anlayışı, s.49.

10 Hobbes, Leviathan, s.82- 83; Locke, Yönetim Üzerine İkinci İnceleme, s.21.

11 John S. Dryzek, The Politics of the Earth, Environmental Discourses, 2. Bask1, New York, Oxford University Press. 2005, s.121-125.

12 Frank De Jong, "Piyasa Kurallarıyla İşleyen Bir Yeşil Ekonominin Temel İlkeleri”, Üç Ekoloji, No.4, Güz, 2005, s.102- 105. 
Diğer taraftan devletin işlevinin daha sınırlı olması gerektiğini savunan liberteryanlar, ekoliberal çevre politikalarını da devletin özel yaşama müdahalesi olarak yorumlar. ${ }^{13}$ Devletin insanların yaşam biçimlerini belirleme, gelecek planlarına müdahale etme misyonuna sahip olmadığının altını çizerler. Devletin çevreyi koruma anlayışını benimseyerek, bu amacı gerçekleştirmek için ekonomiye veya yaşamın herhangi bir alanına yapacağı müdahale, bireysel arzuları yönlendirir. Bir defa devletin bireysel özgürlüklere müdahale edebileceğini kabul etmek, sınırsız bir müdahaleler dizisinin kapısını aralayabilir. Devletin sağlıklı ve temiz bir çevre idealini bireylere dayatma hakkı olmadığı belirtilerek, her türlü hayat tarzına karşı devletin tarafsız kalmasının önemi belirtilir. ${ }^{14}$

Liberteryan görüş, devletin meşruiyetini toplumsal sözleşmeye dayandıran toplumsal sözleşme kuramcılarına karşı çıkar. Örneğin Rothbard’a göre hayatta kalmanın ve bireysel amaçlara ulaşmanın "doğal” yolu üretmek, mülk edinmek ve üretilen malların ticaretinden doğan zenginliğe ulaşmaktır. Devlet ise doğal olarak gelişen meşru bir kurum değil, doğal olana müdahale eden ve el koyan bir aygıttır. İnsanın hayatta kalmasının doğal yolu, kişinin kendi emeğiyle ürettiği ürünleri mülk edinebilmesi, bu ürünleri diğer kişiler tarafından üretilip mülk edinilen mallarla değiştirerek ticari ilişkilere girmesi ve zenginleşebilmesidir. Devletin, bu ilişkiler arasına her girişi, doğal olana müdahale olarak görülür. Rothbard tarafından "siyasi yöntem" olarak tanımlanan devlet müdahalesi, doğal hayatta kalma biçimlerini bozan ve sömüren, yağmacı bir hayatta kalma stratejisidir. Bu nedenlerle devlet ve devletin işlevleri, insanın hayatta kalmasının doğal yollarının sağlıklı işleyebileceği bir ortamı yaratmakla sınırlandırılmalıdır. Devletin bunun ötesine geçen edimleri zora dayanan sömürünün meşrulaştırılmasına neden olacaktır. ${ }^{15}$

Ekolojik sorunlarla mücadelenin devletin meşru görevlerinden olup olmadığı konusu liberal çevrelerce tartışılagelen bir sorundur. Bazı liberaller çevre koruma konusunu da kapsayan çeşitli alanların fiyat mekanizmasına doğru şekilde yansıyamadığını, dolayısıyla ilgili hizmetlerin serbest piyasa işleyişi içinde gerçekleştirilemeyeceğini kabul eder ve bu gibi alanların devlet eliyle idare edilmesini meşru görür. ${ }^{16}$ Yine de devleti ekolojik sorunların çözümü için yetkili kılmak, liberallerde Wissenburg'un satırlarında berraklaşan modern insanın yeşil kırlara hapsedildiği eko-otoriteryan bir distopya korkusu yaratır. ${ }^{17}$ Ekolojik sınırlamalar insanlara ne kadar üretmeleri, tüketmeleri ve nasıl yaşamaları gerektiğini dikte eden kurallara dönüşebilir. Böylece ekolojik gereksinimlerle uyum içinde yaşama arzusu, insanların kendi yaşamlarına yönelik oldukça kısıtlı özgürlüklere sahip oldukları, "yeşil devlet” tarafından tutsaklaştırıldıkları bir düzene evrilebilir. Doğayı korumak amacıyla insanların zorla çevre dostu hayatlara mahkûm kılınacağı korkusu, eşitlik ve adaleti sağlamak amacıyla devletin özgürlükleri sınırlandıracağı otoriteryan devlet korkusunun ekolojik tartışmalardaki yansımasıdır.

13 Coglianese, devletin bireye herhangi bir anlamlı hayatı dayatma hakkı olmadığını dile getirir. Çevresel konularda duyarlı olmak veya çevreyi korumak belirli bir "anlamlı" veya "iyi” hayat tanımının dayatılmasıdır. Anlamlı hayatın ne olduğu konusunda karar vermesi gereken bireylerdir ve bireylerin yaşamlarına ilişkin somut bir riskin yokluğunda, çevresel konularda duyarlılığın dayatılmaması gereğinin altını çizer. Örneğin yok olma tehlikesi altındaki türlerin korunması konusunu, insan yaşamına ilişkin somut bir risk barındırmadığı veya bahsi geçen riskin spekülatif olduğu gerekçesiyle reddeder. Böyle konular devletin doğrudan veya dolaylı olarak müdahale etmemesi gereken konulardır. Aksi halde “çevreye duyarlı yaşam anlayışı”, devlet eliyle bireylere empoze edilmiş olur.

14 Cary Coglianese, “Çevre Politikası İçin Liberal Tarafsızlığın İfade Ettikleri”, Liberal Düşünce, No.27, 2002, s.201- 202; Yusuf Şahin, “Çevre Sorunları ve Liberalizm”, O. İmga ve H. Olgun (der.), Yeşil ve Siyaset, Ankara, Lotus, 2012, s.183.

15 Murray N. Rothbard, Eşitlikçilik: Doğaya Karşı İsyan, İstanbul, Liberte Yayınları, 2009, s.39- 40.

16 Friedrich Von Hayek, Kölelik Yolu, İstanbul, Liberte Yayınları, 2013, s.65.

17 Marcel Wissenburg, Green Liberalism, The Free and The Green Society, London, UCL Press, 1998, s.33. 


\section{Yeşil Devlet}

Liberal özgürlükçü kaygılar, piyasanın çevresel değerleri korumadaki başarısını gündeme taşır. Eğer devletin çevre sorunlarına uzaktan bakması isteniyorsa, önerilen araçlar sorunu çözmede etkili olmalıdır. Ancak ekolojik iktisatçılar, piyasa işleyişindeki temel bazı özellikler nedeniyle, çevre korumanın kendiliğinden serbest piyasa eliyle gerçekleşemeyeceğini savunur. ${ }^{18}$ Efektif talebin olmadığı durumlarda, piyasada ilgili malın üretimi için bir itki bulunmamaktadır. Yeterli talebin bulunmamasını o malın değerine veya o mala duyulan ihtiyaca ilişkin bir gösterge olarak yorumlayan liberal görüşe karşı, yaşamsal önemdeki bazı malların piyasaya efektif talep olarak yansımadığı uyarısında bulunulur. Örneğin toplumda temiz hava için ödeme yapmaya istekli çok az kişi bulunur. Bu nedenle piyasa, temiz hava temin eden araç ve yöntemler üretmeye yönelmez. Ancak, yetersiz talep olması, toplumda temiz havaya ihtiyaç olmadığı veya bireylerin temiz hava solumak istemedikleri anlamına gelmez. Çevre korumaya yönelik hemen her hizmet benzer niteliktedir. Hahnel, çevresel hizmetlerin piyasaya efektif talep olarak yansımaması sorununu kamu malları ile açıklar. Buna göre herkesin ortak kullanımına açık, ortak yararına olan mallar kamu mallarıdır ve bireyler bu malların ücretlerini ödemektense bedavacılık yaparak var olan ve herkese açık olan mallardan ücretsiz biçimde yararlanma yoluna gider. ${ }^{19}$ Çevre koruma veya ekolojik sorunlarla mücadele doğası gereği bir kamu malı olduğu için, gerçek talebin serbest piyasanın arz-talep eğrisine doğru biçimde yansımaması, serbest piyasanın ekolojik sorunları çözmedeki yetersizliğini ortaya koyar. Bu nedenle devletin sorunlara karışmayıp uzaktan izlemesini istemek gerçekçi bir yaklaşım değildir. Eckersley’e göre sorun, insanların ekolojik kaygılar beslememesi, yani piyasada ekolojik ihtiyaçlara yönelik yeterli talep olmaması değil liberal demokrasilerin ekolojik krizle başa çıkamıyor olmasıdır. Ona göre ekolojik sorunlar ekonomik, bilimsel ve siyasal yapıların bir sonucudur ve çözüm için yine aynı yapılardan medet umulmaktadır. Liberal devlet ise ekolojik krizin öneminin bilincinde olmasına karşın, varllğını sürdürebilmek için krizi inkâr etme, önemsizleştirme ve doğallaştırma yoluna gitmektedir. ${ }^{20}$

Hobbes'çu dünya görüşünü ekolojik açıdan geliştiren Olphus, ekolojik krizle mücadelenin merkezinde devlet otoritesine ihtiyaç duyulduğunu savunur. Bireysel özgürlükleri öncelikli alan liberal dünya görüşünü, doğanın sınırsızca sömürülmesinin temel nedeni olarak gösterir. Bireysel özgürlükler ve kişilerin geleceklerini belirleme haklarına önem veren liberalizmi eleştirerek, doğal kaynakların yok olmakla yüz yüze olduğu, yakın gelecekte kimsenin gelecek planları yapıp dilediği gibi yaşayacak imkânı olamayacağı uyarısında bulunur. Olphus’a göre liberalizmin trajedisi, hayal ettiği dünya ile yarattığı dünya arasındaki tezattır. Liberalizm teorik olarak kendini, bireyin otonom gücünü, devletin potansiyel gücüne karşı korumaya adamıştır. Oysa liberal politikaların pratikteki etkisi, ileri bir tiranlığa boyun eğmiş, bağımlı bir işçi sınıfı yaratmak olmuştur. Liberal devlet ise kontrolsüz bürokratik aygıtlarıyla, davalarla, baskı, hile ve zorlamayla insanları yöneten yeni bir tür mutlak devlet haline gelmiştir. Dolayısıyla liberal devlet asla küçük veya insan hayatından uzakta değildir. Toplumda iktisadi büyümeyi arttırmak için sürekli büyüyen ve güçlenen ancak toplumun ihtiyaç duyduğu gerçek hizmetleri verme becerisinden uzak bir devlettir. ${ }^{21}$ Bireysel özgürlüklere ve birbirinden yalıtılmış farklı

18 Arthur Cecil Pigou, Wealth and Welfare, New York, Cornell University Library, 2009; K.W. Kapp, The Social Costs of Private Enterprise, Boston, MA, Harvard University Press, 1950,

19 Robin Hahnel, Yeşil İktisat, İstanbul, Boğaziçi Gösteri Sanatları Topluluğu Yayınları, 2014, s.82.

20 Robyn Eckersley, The Green State, Rethinking Democracy and Sovereignty, Massachusetts, The MIT Press, 2004, s.90-94.

21 William Ophuls, Requem for Modern Politics, The Tragedy of the Enlightenment and the Challenge of the New Millennium, Colorado, Westview Press, 1997, s.263. 
yaşam biçimlerine saygı duyan, tekil bireye dayalı liberal dünya anlayışı, dünyanın ender kaynaklarını sömüren ve kıtlığa yol açan bir hayat biçimidir. Hobbes'un savaş durumunu andıran ekolojik krizden kurtulup, insanlığın yüz yüze olduğu kıtlık sorunlarını aşabilmek, güçlü bir Leviathan tarafından düzenin tekrar sağlanmasıyla mümkün olabilir. Böyle bir düzende, bireysel yaşam planları değil, toplumsal gereklilikler ve huzur ortamı temel hedef olarak benimsenir. ${ }^{22}$

Ekolojik kriz ve kıtlıkla mücadele yöntemini belirlerken otoriteryan bir yaklaşım benimsemek, genellikle demokratik uygulamaları uzaklaştırmayı da beraberinde getirir. Demokratik yaklaşımdan uzaklaşma eğilimi ise iki etmene bağlanmaktadır; bunlardan ilki Hobbes'un insanın kendi haline bırakıldığı zaman özgeci bir tutum sergilemeyeceğine yönelik inancın benimsenmesidir. İkinci etmen ise amaca ulaşmak için benimsenen araçları önemsemeyen, sonuç odaklı politikalardır. Bu anlamda eko-otoriteryanizm araçları görmezden gelen sonuç odaklı bir yaklaşım olarak değerlendirilir. $\mathrm{Bu}$ görüşe göre insanlığın önünde iki seçenek vardır; ya ekolojik sorunlarla başa çıkabilmek için otoriteryan bir yaklaşım benimsenir veya kaçınılmaz olarak ekolojik kriz sonucu oluşacak olan yıkımla yüzleşilir. Hedeflenen amacın yaşamsal önem taşıdığı durumlarda, amacın ona ulaşmak için seçilen araçları öncelemesi gerektiğini savunur. Ekolojik sorunlarla mücadele ederken demokratik araçların tercih edilmesi daha doğru bir yöntem olacaksa da, insanların yeterli bilgi ve duyarlılık düzeyine ulaşmaları için çok zaman kaybedilecek ve ekolojik sorunlarla mücadele etmek için geç kalınmış olacaktır. Diğer taraftan Dobson, demokratik uygulamaları dışlayan yaklaşımların ekolojik harekette benimsenmediğini vurgular. ${ }^{23}$ Krizin güçlü bir otorite tarafından konan sınırlamalarla değil, ekolojik bilince ulaşmış bireylerin kendi kendileri üzerinde geliştirecekleri sınırlamalarla aşılabileceğini ifade eder. Mills'e göre ${ }^{24}$ Hobbes'çu insan doğası anlayışıla, politik kararların üstünkörü bir biçimde kontrol mekanizması olmadan merkezi bir otoriteye sevk edilmesi, sorun yaratma potansiyelini de beraberinde getirir. Eko-otoriteryanlar tarafından özlenen ve demokrasiyi devre dışı bırakan devlet biçimi, önlemeyi amaçladığı sorunların ötesinde problemlere gebedir.

Diğer taraftan devletin ekolojik sorunlar konusunda bir taraf olup olmamasının geçerli bir tartışma olmadığı, devletin zaten hali hazırda konunun en önemli aktörü olduğu dile getirilir. Tartışılması gereken asıl mesele devletin yeşil politikalarda bir aktör olması veya olmaması gerektiği değil, ekolojik sorunlar karşısında nasıl bir devlete ihtiyaç duyulduğu olmalıdır. Devlet bugün sahip olduğu gücü serbest piyasaya borçludur ve bu gücün sürdürülebilmesi, piyasanın işleyişini koruyan bir takım işlevlerin yerine getirilmesiyle mümkündür. Özel mülkiyetin tahsisi ve güvence altına alınması, ticari kanunlar, vergilendirme ve işçi- işveren ilişkilerinin denetimi gibi işlevler, devlet ile serbest piyasaya sahip oldukları gücü veren ve aralarındaki işbirliğini gerektiren temel fonksiyonlardır. ${ }^{25}$ Ekolojik kaygılar veya gereksinimler bu fonksiyonlarla uyumlu bir biçimde varlıklarını sürdürebildikleri sürece devlet ekolojik ihtiyaçlara cevap verebilir.

Ekolojik modernizm, devletin çekirdek fonksiyonlarına meydan okuyan hareketlerin yok olmaya mahkum olduğuna, bununla beraber ekolojik hareketlerin devletle uyumlu bir birliktelik

22 William Ophuls, Plato's Revenge, Politics in the Age of Ecology, Massachusetts The MIT Press, 2011, s.188.

23 Andrew Dobson, “Ecologism”, R. Eatwell ve H. Wright (der.), Contemporary Political Ideologies, Pinter, Routledge, 1993, s.234.

24 Mike Mills, “Green Democracy: The Search for an Ethical Solution”, B. Doherty and M. De Geus (der.), Democracy and Green Political Thought, Sustainability, Rights and Citizenship, New York, Routledge, 1996, s.96.

25 John Barry ve Robyn Eckersley, "W(h)ither the Green State”, J. Barry and R. Eckersley (der.), The State and the Global Ecological Crisis, Massachusetts, The MIT Press, 2005, s.255-256. 
kurmasının mümkün olduğuna inanır. Buna göre erken dönem devletin üç çekirdek görevi vardır; iç düzeni korumak, devletler arası ilişkileri sürdürmek ve ilk iki görevi yerine getirebilmeyi sağlayacak finansal kaynaklar yaratmak. Kapitalizmin gelişimiyle büyüyen ekonomi, devletin gelirlerinin artmasına neden olur, devletin sahip olduğu çekirdek görevlerin gelişimine yol açar; ekonomik gelişimi korumak da böylece devletin çekirdek fonksiyonlarından biri haline gelir. Ekonomik büyüme, onu yaratan burjuva sınıfını korumak anlamına geldiği için, burjuva sınıfının hareketini kısıtlayabilecek faktörlerin engellenmesi de görevler arasında yerini alır. Bu çekirdek fonksiyonlara karşı geliştirilen muhalif hareketler şiddetle baskılanır. Ekolojik hareketler de genellikle muhalif hareketler arasında yer alması nedeniyle bastırılma eğilimindedir. Ancak, ekolojik modernizmi savunanlara göre böyle olmak zorunda değildir. Devletin çekirdek foksiyonları ekolojik ihtiyaçlarla uyumlu olabilir. Ekolojik talep ve ihtiyaçlar, devletin çekirdek fonksiyonları içinde kendine yer bulabildiği ölçüde, devletin gücü ve desteğini arkasına alabilecektir. ${ }^{26}$

Diğer taraftan ekolojik sorunlar çok boyutludur ve birbirinden farklı pek çok alana yayılmış durumdadır. Martinez’in de belirttiği gibi, ekolojik sorunların doğasında olan farklılıklar pek çok şeyi değiştirir. Söz gelimi vahşi yaşamı korumak, devletin serbest piyasa sistemini muhafazası için üstlendiği temel fonksiyonların işleyişine engel oluşturmaz, dolayısıyla devletin fonksiyonları arasında varlığını rahatlıkla sürdürebilir. Ancak, yoksulluğun ekolojisi gibi sorunlar, ekolojik risklerin sınıflar arasında eşit dağılmadığı ve işçi sınıfının ekolojik risk pastasından en büyük payı almasının bir sorun olarak ortaya konması, sisteme bir saldırı olarak yorumlanır ve bu gibi ekolojik sorunların çözümü devletin temel fonksiyonları arasında yer alamaz. ${ }^{27}$ Sorunların sınai inovasyonlar ve gelişen teknolojilerle, daha etkili, verimli ve akılcı yöntemlerle çözülebileceğini savunan ekolojik modernizm yaklaşımı, tüm tarafların kazanabileceğini ve ekolojik krizle mücadele ederken sahip olduğumuz yaşam standartlarından ödün vermemiz gerekmediğini dile getirir. Ancak bu yaklaşım, ekolojik sorunları olduğu gibi bütün boyutlarılla ele alma becerisine sahip değildir. Ekonomik sistemin ihtiyaç duyduğu yapısal dönüşümler, mülkiyet sisteminin yarattığı sorunlar veya serbest piyasa sisteminin sınırlılıkları, ekolojik modernizmin görmediği, göremediği alanlardır. Büyümeyi temel alan bakış açısıyla, daha az girdiyle daha çok üretme özlemi taşırken, tüketim sorunsallarıyla ilgilenmez. Dahası ekolojik sorunların dağılımı ve adalet gibi konuları yok sayar.

Barry ve Eckersley'e göre devletin yeşil düşünce tarafından giderek artan bir biçimde ekolojik yıkımın temel aktörlerinden biri olarak görülmesi, ekolojik sorunları çözme potansiyeli en güçlü aktörün saf dışı bırakılmasına neden olmaktadır. Onlara göre devletin ekolojik konularda hem yapıcı hem de yıkıcı bir etkiye sahip olduğu bir gerçektir. Ancak Rousseau'nun değindiği gibi devletin ne olduğu kadar ne olabileceğini de dikkate almak ve taşıdığı potansiyeli değerlendirebilmek gerekir. ${ }^{28}$ Eckersley uluslararası düzlemde devletin davranışlarının giderek Hobbes'çu anlayıştan uzaklaşarak, Locke'çu bir anlayışa yaklaştığını savunur. Devletler birbirleriyle ve sivil toplum kuruluşlarıyla işbirliği içinde hareket ederek sorunları çözmek için farklı platformlar yaratmaya başlamıştır. Devlete alternatif yönetim biçimleri arayışındansa, politik ekolojinin çevre sorunlarını devlet çıkarlarıyla ilişkilendiren ve tehdidi ulusal boyutta algılayan Hobbes'çu yaklaşımın dönüştürülmesine odaklanması gerekir.

26 John S. Dryzek et al., Green States and Social Movements, Environmentalism in the United States, United Kingdom, Germany, and Norway, New York, Oxford University Press, 2003, s.165.

27 Joan Martinez Alier, The Environmentalism of the Poor, A Study of Ecological Conflicts and Valuation, Massachusetts, Edward Elgar, 2002, s.203.

28 Barry ve Eckersley, "W(h)iter the Green State?”, s.256. 
Ekolojik sorunlar doğaları gereği küresel bir bütünlük arz eder. Ekolojik tehdidin bölgesel ve ulusal sınırların ötesinde, gezegenin bütünselliği çerçevesinde algılanması, devletlerin uluslararası davranışlarında Hobbes'çu kültürün yerini Kant'çı sorumluluk kültürü bağlamında Locke'çu bir anlayışa terk etmesini sağlayabilir. Böylesi bir dönüşüm özgürlük, otorite ve devletin varlık sebebi gibi kavramların yeniden düşünülmesini/tanımlanmasını gerektirecek ve ortak iyiye ulaşılabilesi için farklı yöntemler geliştirilmesine yol açabilecektir. ${ }^{29}$

Uluslararası sistemde böylesi bir dönüşüm gerçekleşebilse dahi bahsi geçen dönüşümün ekolojik sorunlara yönelik yeterince hızlı ve etkili çözüm sunabileceği konusu ise belirsizliğini korumaktadır. Dahası devletin sahip olduğu çekirdek fonksiyonlar böylesi bir dönüşümden önemli ölçüde etkilenmeyecek, ekonomik gereksinimler ekolojik gereklilikleri öncelemeye devam edecektir. Buna karşın Eckersley yine de umudunu koruyarak yeşil hareketlerin büyümeye devam etmesi, yeşil partilerin yerel, ulusal ve bölgesel ölçekte etkisini arttırabilmesi, diğer taraftan çevresel bozulmaların olumsuz sonuçlarının görünürlüğünün ve maliyetinin giderek artması durumunda, ekonominin ekolojiyi öncelediği hiyerarşinin alt üst olabileceğini dile getirmektedir. Böylelikle çevre koruma devletin fonksiyonları içinde merkezi bir konuma yerleşebilecek, devlet, piyasanın dikte ettiği sınırlılıklardan uzaklaşıp yeryüzünün ihtiyaç duyduğu korumayı sağlayabilecek, ekolojik riskleri, sınırlılıkları ve ilkeleri benimseyen daha yeşil bir devlete dönüşebilecektir. ${ }^{30}$

\section{Ekolojik Riskler ve Eşitsizlik}

Pek çok biliminsanı, bugün yaşanmakta olan ekolojik krizi uygarlığın karşılaştığı en büyük karışıklık dönemi olarak nitelemektedir. Başka bir deyişle modern devlet, sözleşme kuramcılarının devletin varlık nedeni olarak gördükleri yeni bir kaos, bir savaş durumuyla yüz yüzedir. Ekolojik sorunların ortaya çıktı̆̆ı 1950'li yıllardan bugüne kadar alınan önlemler sonuçsuz kalmış, yaşanılan kriz günden güne büyüyerek karmaşıklaşmıştır. Özellikle kentleşme ve sanayileşmenin ekosistem üzerinde karmaşık ve çok boyutlu bir baskı yarattığı kabul edilmektedir. Kentler, üretim ve tüketim merkezleri haline gelirken doğal alanlar ve ekolojik süreçler tahrip olmaktadır. Gıda ve sanayi üretimini arttırma ihtiyacı, ormanlık veya doğal alanların tarlalara ve sanayi bölgelerine dönüştürülmesine neden olmakta, bu durum insan dışındaki türlerin yaşam alanlarının yok olması anlamına gelmektedir. İnsan dışındaki türlerin yaşam alanlarının yok edilmesinin bugün yaşanan ve büyük kitlesel yok oluşlarla kıyaslanan türsel yok oluşların en önemli nedeni olduğu düşünülmektedir. Kentleşme ve sanayileşmenin bir diğer sonucu olan ormansızlaşmanın, yeryüzündeki canlılık için yaşamsal önemdeki su döngüsü üzerinde de olumsuz bir etki yarattığı bilinmektedir. Ormansızlaşmanın diğer bir etkisi ise doğal karbon rezervlerinin yok olmasıdır. Çağımızda yoğun fosil yakıt tüketiminin temel sonucu, atmosferdeki sera gazı yoğunluğunun artmasıdır. Ormansızlaşma, karbon tutulumunun azalmasına neden olarak atmosferdeki sera gazı oranlarının artmasının ikincil nedenidir. ${ }^{31}$ Küresel iklim değişikliğinin gezegende büyük çaplı biyoçeşitlilik kaybı, iklim kalıplarında altüst oluşlar, gıda ve su kıtlıkları, gezegensel su seviyelerindeki değişime bağlı büyük göç hareketleri gibi büyük çaplı

29 R. Eckersley, “Greening the Nation-State: From Exclusive to Inclusive Sovereignty”, J. Barry and R. Eckersley (der.), The State and the Global Ecological Crisis, Massachusetts, The MIT Press, 2005, s.165-168.

30 Barry ve Eckersley, "W(h)ither the Green State”, s.265- 266.

31 L. S. Kuchment, A. N. Gelfan ve V. N. Demidov, "Modeling of the Hydrological Cycle of a Forest River Basin and Hydrological Consequences of Forest Cutting”, The Open Hydrology Journal, Vol.9, No.5, 2011, s.17. 
değişim ve dönüşümlere neden olacağı tahmin edilmektedir. ${ }^{32}$ Diğer taraftan artan nüfusa bağlı olarak besin ihtiyacına cevap verebilmek üzere yaygınlaşan zirai kimyasal kullanımı, sanayide kullanılan kimyasallarla birlikte ekosistemleri zehirlemektedir. Yeryüzü su döngüsünün çok küçük bir bölümünü oluşturan tatlı su döngüsü, kimyasal atıklar nedeniyle artan bir kirlenme baskısıyla karşı karşıyadır. ${ }^{33}$ Kimyasallar milyarlarca canlının içme suyu olarak kullandığı temiz su kaynaklarına karışmaktadır. Okyanuslarda ölü bölgelerin oluşması, asit yağmurları, çölleşme, erozyon, sel baskınları, yer altı sularının çekilmesi, ozon tabakasının incelmesi gibi birbiriyle ilişkili pek çok gezegensel sorun, günümüzde acilen çözümlenmesi gereken sorunlar olarak ortaya konmaktadır. Bilim insanları gezegende yaşamı mümkün kılan hassas dengelerin zorlanmakta olduğunu ve anlamlı değişimlere gidilmediği takdirde ekolojik çöküşlerle yüz yüze kalabileceğimizi dile getirmektedir.

Crutzen, geçtiğimiz birkaç yüzyıl içinde insan nüfusunun katlanarak artması ve etkisinin yeryüzünün büyük bir bölümüne yayılmasının altını çizerek insanın artık doğal süreçlerde önemli bir güç haline geldiğini savunmaktadır. Meteor çarpması gibi küresel bir felaket meydana gelmediği sürece, insanlığın gelecek bin yılda da yeryüzündeki en etkili güç olacağını öngörmekte ve içinde bulunduğumuz çağı Antroposen olarak isimlendirmektedir. ${ }^{34}$ Böylece Antroposen tanımı, gezegende yaşayan milyonlarca tür içinde bir tanesinin, insanın önemini ve etkisini ortaya koymaktadır. İnsanın dünyaya verdiği zararın boyutları doğal afetlerin çok ötesine geçerek meteor çarpması gibi gezegensel felaketlerle birlikte anılmaktadır.

Diğer taraftan çağımızın Antroposen olarak nitelenmesi popülerleşmiş ve pek çok biliminsanı tarafından kabul görmüş olsa da, bu tanıma önemli gerekçelerle meydan okunmaktadır. Karşı görüş, Antroposen tanımının ekolojik sorunların bir tür olarak insana atfedilmesine karşı çıkar. Malm ve Hornborg ${ }^{35}$, Crutzen'in Antroposen çağını eleştiren çalışmalarında, insanı dünyayı dönüştüren jeolojik bir güç olarak tanımlamanın, sorunların asıl nedeninin üstünü örttüğü görüşündedir. Crutzen’ in Antroposen kurgusu, buharmakinesininicat edilmesive sanayi devrimigibiolayları kronolojikolaraksorunun başlangıcı olarak ele alır ve ekolojik krize neden olan tüm gelişmeleri bu olaylardan türeyen zorunlu ve önlenemez sonuçlar olarak değerlendirir. Böylece, sanayileşmeyi tetikleyen temel nedeni gözden kaçırmış olur. Birkaç yüzyıl önce ortaya çıkan ve sanayi devriminden bu yana artarak şiddetlenen gezegensel dönüşümler bir tür olarak insana ait özelliklerle, insan doğasıyla açıklanır. Bu görüş insanın, yalnızca insan olduğu için, karakteri gereği zorunlu olarak bu noktaya geldiği ve insanlığın ekolojik yıkımdan eşit derecede sorumlu olduğu imasını taşımaktadır. Oysa sanayileşme çok küçük bir zümre tarafından planlanmış, finanse edilmiş ve desteklenmiştir. Fosil yakıtların kullanımı, kapitalist ekonominin ihtiyaç duyduğu büyüme hızına cevap verdiği için desteklenmiştir. Ancak fosil yakıtların kullanımı için ne tüm insanlıktan onay alınmış ne de kazanç tüm insanlarla bölüşülmüştür. İlerleyen zamanlarda da temel kalıplar değişmemiş, elektrik, içten yanmalı motor, petrol, arabalar ve bunun gibi yeryüzünü dönüştüren önemli gelişmeler, yatırım yapanın kâr hesaplamalarına bağlı olarak planlanmış ve finanse edilmiştir. Dünya nüfusunun \%18,8'ini oluşturan gelişmiş kuzey ülkeleri, karbon emisyonunun \% 72,2'sinden sorumludur. Dünyanın en fakir \% 45 'lik kesimi karbon emisyonlarının \%7'sine neden olurken, en zengin \%7, tüm karbon emisyonlarının yarısına neden

32 IPCC, Climate Change 2014, Assessing and Managing the Risks of Climate Change, Cambridge, United Kingdom and New York, Cambridge University Press.

33 N. Gruber ve J. N. Galloway, “An Earth-System Perspective of the Global Nitrogen Cycle”, Nature, Cilt 45, Ocak 2008, s.293.

34 P. J. Crutzen, “Geology of Mankind”, Nature, No.415, 2002, s.23.

35 A. Malm ve A. Hornborg, "The Geology of Mankind? A Critique of the Antropocene Narrative", The Anthropocene Review, Cit XX, No.X, 2014, s.2-3. 
olmaktadır. O halde, insanları ekolojik krizden eşit derecede sorumlu tutmak, asıl sorumluları aklamaktır. Dünyaya, beş büyük yok oluşla kıyaslayacak derecede büyük zarar veren asıl neden kapitalizmdir. ${ }^{36}$ Bir tür olarak insan nasıl sorunların ortaya çıkmasında eşit derecede sorumlu değilse, ekolojik risklerin dağılımı da eşit bir biçimde gerçekleşmemektedir. Yapılan araştırmalar ekolojik sorunlardan en az sorumlu olan kesimin, sonuçlarından en fazla zarar görenler olduğunu doğrulamaktadır. Bununla birlikte ekonomik büyüme pastasından en büyük payı alanlar, aynı zamanda ekolojik risklerden yalıtılmış bir yaşamı finanse etme gücüne sahiptir. Oysa, ekolojik riskler üzerinde çok az payı olan sınıflar, ekolojik risklere en fazla maruz kalanlardır. ${ }^{37}$

Doğanın sermayenin faaliyetlerinde sürekli olarak kullanılması, yoksul sınıfların yaşamlarını idame etme amaçlı kullanımlarının önünde bir engel olarak belirir. Doğa, sermaye birikiminin aracı olması nedeniyle sermayedar için değişim değerinden ibarettir. Oysa yerel halklar için doğa kullanım değerini ifade eder. Doğa, onlar için barınacak yer, yiyecek yemek ve içecek sudur. Üretim etkinliklerinin amacı değişim değeri yaratmak değil, yaşamlarını sürdürebilmek için kullanım değeri yaratmaktır. Ancak doğa sermaye birikimi için artan bir biçimde kullanıldıkça, yerel halkların temel kullanım mallarına ulaşımları sınırlanır veya tamamen engellenir. ${ }^{38}$ Örneğin temiz suya ulaşım, yoksul kesimler için önemli bir sorun halini almıştır. Sanayi ve tarımsal üretim ve çeşitli madencilik faaliyetleri sonucu şehir sularının ağır metaller ve kimyasal maddelerle kirlenmesi, şişelenen temiz suyu pazarda önemli bir rant aracına dönüştürmüştür. Ancak gücü yetenin finanse edebildiği temiz suya ulaşamayanlar su kıtlığı veya kirli su tüketimine bağlı sağlık sorunları ile karşı karşıya kalır. Bunun yanı sıra, suyun pazarlanabilir bir meta halini alması, az gelişmiş ülkeleri su kaynaklarını özelleştirmeye özendiren bir mali fırsat olarak görülmektedir. Su şirketlerine satılan veya uzun dönemler için kiralanan su kaynakları, bölge halklarının suya ulaşımını engelleyen ve dolayısıyla temel yaşam haklarını ihlal eden boyutlara ulaşmaktadır. Şirketler tarafından kiralanan su kaynakları aşırı kullanıma bağlı olarak kısa sürede yok olmakta ve yerel halkların yanı sıra bölge ekosistemlerine büyük hasar vermektedir. ${ }^{39}$

Sermaye birikimi ile doğanın tahribi ve yoksulluğun artışı arasında olumlu bir ilişki vardır. Öyle ki sermaye birikimi zorunlu olarak doğal varlıkları sömürmekte ve aynı şekilde yoksulluğun artmasına neden olmaktadır. Yoksulluğun artışı ve ekolojik sorunlar sebep-sonuç ilişkisi içinde karşılıklı olarak birbirlerini doğurmaktadır. ${ }^{40}$ Yoksulluğun bugünkü boyutlara ulaşmasına neden olan ve ekolojik krizin merkezinde yer alan temel unsur doğanın taşıdığı değişim değeri ile kullanım değeri arasındaki çelişkidir. Kapitalist sistemin bir sonucu olarak değişim değerinin kullanım değerinden daha baskın hale gelmesi, doğanın kullanımında ve dönüştürülmesinde metanın ve rantın öncelendiğine işaret etmektedir. Harvey'in de belirttiği gibi dünya üzerindeki dönüşüm, artık insanların rahat ve refahlarını arttırma amacıyla değil, sermaye birikiminin devamını mümkün kılmak amacıyla gerçekleşmektedir. ${ }^{41}$

36 Ibid, s.3; T. Fotopoulos, "Myths on the Ecological Crisis", The International Journal of Inclusive Democracy, Cilt 3, No.2., 2007, s.1.

37 Rob Nixon, Slow Violence and the Environmentalism of the Poor, Massachusetts, Harvard University Press, 2011, s.37; Aykut Çoban, "Sınıfsal Açıdan Ekolojik Mücadele, Demokrasinin Açmazları ve Komünizm”, Yaşayan Marksizm, Cilt 1, No.1, 2013, s.245- 246; Jeremy Seabrook, Children of Other Worlds, Exploitation in the Global Market, Virginia, Pluto Press, 2001, s.52; Martinez Alier, The Environmentalism of the Poor, s.104- 132.

38 Necla Yıkılmaz, Yeni Dünya Düzeni ve Çevre, İstanbul, Sosyal Yardımlaşma Vakfı Yayınları, 2004, s.84- 85; Paul Burkett, Marx ve Doğa, Al- Yeşil Bir Perspektif, İstanbul, Epos Yayınları, 2004, s.264-265.

39 Maude Barlow, Mavi Sözleşme, Küresel Su Krizi ve Su Hakkı Mücadelesi, İstanbul, Yordam Kitap, 2009; Çoban, Sımıfsal Açıdan Ekolojik Mücadele, s.247.

40 Yıkılmaz, Yeni Dünya Düzeni ve Çevre, s.86- 87.

41 David Harvey, On Yedi Çelişki ve Kapitalizmin Sonu, İstanbul, Sel Yayınları, 2015, s.251. 


\section{Aldatıcı Ortaklaşma}

Bugün karşı karşıya olduğumuz ekolojik krizin yeryüzünde karşılaşılan en önemli sorunlardan biri olduğuna ilişkin kaygılar artarken, liberalist yaklaşım devletin bu soruna karşı tarafsızkalması gerektiğini savunarak devleti işlevsizleştirme eğilimindedir. Devletin doğal çevre konusunda tarafsız kalması, çatışan sınıflardan hâkim olanın ezilen sınıf üzerinde büyük bir güce sahip olmasını kolaylaştırır. Böylece doğal alanların sermaye üretimi için ezilen sınıfların kullanımından uzaklaştırıldığı bir pratik meşrulaştırılır ve yaygınlaşır. Çatışan iki sınıf arasında denge kurma ve eşitliği gerçekleştirme becerisi en yüksek kurum olan devletin dengeleyici mekanizmasının devre dışı bırakılması yoluyla toplumsal kaosun ve çatışmaların süregitmesi sağlanır. ${ }^{42}$ Liberal demokrasilerde devletin sınıflar arasında tarafsız kalması gerektiği ifade edilse de aslında devlet hiçbir zaman tarafsız değildir ve her zaman sınıflardan birinin yanında yer alır. ${ }^{43}$

Devletin çatışan sınıflar arasındaki taraf olan tavrı genellikle ekolojik uzlaşmazlıklarda açık şekilde görülebilir. Bunun temel nedeni ekolojiyle ilgili konuların bir taraftan çevrenin korunmasının genel kamu yararı içermesi yani toplumsal ortak fayda taşıması, diğer taraftan çevrenin sermaye için hammadde olması nedeniyle berrak bir çıkar çatışması ortamı yaratmasıdır. Doğal hayat üzerinde gerçekleşen çıkar çatışmalarında devlet, doğal kaynaklardan yaşamsal ihtiyaçlarını karşılamak adına yararlanan yerel halklara karşı, işletmelerin, girişimcinin, yatırımcının kısaca sermayenin tarafında yer almaktadır. Foster ve Magdoff ${ }^{44}$ devletin bu tavrını siyasi liderlerin ekonomik kazancı toplumun genel çıkarıyla uyumlu görmeleriyle açıklar. Onlara göre siyasi liderler arasında, kapitalist işletmelerin gelişmesinin ülke için daha iyi olduğu görüşü hâkimdir. Bu yaygın inanç, siyasilerin kendilerini giderek artan bir biçimde siyasi girişimciler olarak görmelerine ve girişimcilerin önündeki engelleri kaldırmanın gerçekten kamusal yarar doğuracağını varsaymalarına neden olmaktadır. Öte yandan doğal alanlar üzerinde kararların siyasi mekanizma tarafından ekonomik fayda ekseninde alınması, devletin yurttaşların genelini değil, egemen sınıfın faydasını koruduğuna işaret eder. Bu noktada, toplum sözleşmesi kuramcılarının ileri sürdükleri gibi devletin asıl görevi yurttaşlara barış ve huzur ortamı sağlamaktan ziyade, mülk sahibi sınıfların çıkarlarını korumaya evrilmiştir. Devlet, sınıflar arasında bir arabulucu olarak görünse de, aslında ezilen sınıfların yüz yüze kaldığı riskleri ve felaketleri yok sayar ve son tahlilde egemen sınıfın çıkarlarını gözetir. ${ }^{45}$

Toplum sözleşmesi kuramcılarının devleti medeni yaşamın temeli olarak resmeden yaklaşımına karşı Marksist yaklaşım, tarihsel bir perspektifle devletin tarih boyu sınıf çatışmalarının ortasında doğup, çatışan çıkarlardan egemen sınıfın yararına uygulamalar geliştirdiğini savunur. Devlet her zaman iktisadi olarak ve aynı zamanda siyasi olarak egemen olan sınıfın çıkarlarını koruma görevi yüklenir. Toplumda barışın ve refahın sağlanmasının bir aracı olarak resmedilmesi, devletin tüm yurttaşlar tarafından benimsenmesi için kurgulanan bir yanıltmacadır. Toplumsal sözleşme teorisyenlerinin ortaya koyduğu gibi bu toplum durumu herkes için huzur ve barış getiren bir düzen olmaktan çok uzaktır. Aksine egemen sınıfın diğerleri üzerinde kurduğu tahakküm ve sömürü düzeni, ezilen sınıf açısından barış ve huzur getirmemiştir. Bu nedenle tüm diğer sınıflı toplumlar gibi kapitalizm de,

42 Ibid s.173, John B. Foster ve Fred Magdoff, Her Çevrecinin Kapitalizm Hakkında Bilmesi Gerekenler, İstanbul, Patika Kitap Yayınları, 2014, s.118-119.

43 Henri Lefebvre, Sosyalist Dünya Görüşü Marksizm, İstanbul, Yordam Kitap, 2010, s.117- 118.

44 Foster ve Magdoff, Her Çevrecinin Kapitalizm Hakkında Bilmesi Gerekenler, s.118.

45 Lefebvre, Sosyalist Dünya Görüşü Marksizm, s.117-118. 
ezilen sınıfın sistemin sınırları içinde kalmasına yardımcı olacak, düzeni devam ettirmeyi sağlayacak bir takım araçlara ihtiyaç duyar. Halkın mevcut durumu kabullenmesini sağlamak ve aksi durumda direnci bastırmak gibi işlevler devlet eliyle gerçekleştirilir. Bu nedenle, devletin ortaya çıkışı ancak sınıf çatışmaları ile açıklanabilir. Nasıl köleci toplumlarda köle sahiplerini, feodal toplumlarda toprak sahiplerini koruyup köleleri ve serfleri dizginleme görevi görüyorsa, kapitalist toplumda da işçi sınıfını dizginleyip sermayedarları koruma görevi görür. Devlet nezdinde tüm yurttaşların eşit önem ve değerde olduğu inancı, bu anlamda yurttaşların onun varlığını benimsemeleri için önemlidir. Sınıflar arası çatışmalarda uzlaşı ve barışı sağlayan bir üst otorite olarak görülmekle birlikte, gerçek fonksiyonu daima egemen sınıfın çıkarlarını korumaktır. Devlet, bazı durumlarda sömürülen sınıfı korur gibi göründüğünde dahi, aslında uzun vadede egemen sınıfın çıkarlarını ve sistemin sağlıklı işlemesi için gerekli dengeleri korumaktadır. ${ }^{46}$ Böylece Marksist teori devletin varlı̆̆ını sınıflı topluma dayandırır. Sınıf çatışması devletin varlık nedeni olduğu kadar, onu var eden unsurları korumak kaydıyla, bu çatışmayı dizginlemek ve yumuşatmak devletin temel görevidir. Engels'in belirttiği gibi, devletin görev ve yetkileri, antik devletten köleci devlete, feodal devletten modern devlete dönüşürken değişir ve toplumsal düzen ve egemen sınıfın ihtiyaçları tarafından yeniden tanımlanır. ${ }^{47}$

Ancak kapitalist toplumda devlet, önceki toplumlardaki devlet anlayışından bir anlamda farklılaşmıştır. Liberal ideoloji etrafında şekillenen kapitalizm, öyle olmamasına rağmen ezilen sınıfın özgür olduğu izlenimi yaratır. Gerçekten de yasal anlamda hiçbir zorlayıcı baskı altında tutulmayan işçi sınıfı, önceki toplumlardaki gibi zorla çalıştırılmaz. Ancak üretim araçlarından uzaklaştırıldığı için hayatta kalmasının zorunlu bir koşulu olarak "özgürce” çalışmayı seçmek zorunda bırakılır. Bu nedenle kapitalist devlet tüm yurttaşlara eşit mesafede, taraf tutmayan ve yurttaşların haklarını ve özgürlüklerini koruyan bir devlet görüntüsü çizer. Aslında koruduğu özgürlük, temelde, sermaye sınıfının işçi sınıfının artı- ürününe el koyma özgürlüğü olduğu halde, toplumun ortak tek bir çıarı olduğu fikri oluşturularak sınıf çatışması gölgelenmek istenir. Böylece, ezilen sınıflar ortak fayda için çalıştıklarını düşünürlerken egemen sınıf için üretmeye devam edecektir. ${ }^{48}$

Aynı yanıltmaca, devletin ekolojik sorunlar karşısındaki konumlanışında da görülmektedir. Yeryüzündeki doğal kaynaklar sınırlıdır ve hali hazırda mevcut üretim ve tüketimin tahrip ettiği doğal sistemlerin daha fazla büyümeyi ve daha fazla tüketimi taşıma kapasiteleri bulunmamaktadır. Ekolojik altüst oluşun arkasındaki temel neden sanayileşmenin ve kentleşmenin artışıyla doğrusal olarak artan kaynak tüketimi ve atık sorunudur. Sorunun çözülebilmesi daha az büyüme, daha az sanayileşme, daha az enerji tüketimi ve doğal alanların daha az kirletilmesiyle mümkündür. Oysa siyasi ile iktisadi alanın birbirinden ayrılması sonucu devletin doğal varlıklar üzerindeki denetimini serbest piyasaya bırakması, sorunun daha çetrefil hale gelmesine neden olmaktadır. Metalaştırılan ve piyasa eline bırakılan doğal varlıklar, siyasi karar alıcıların sorumluluğundan çıkarılarak iktisadi alanın kendiliğinden gelişen süreçlerine tabii kılınır. Böylelikle ekonomik özgürlük alanının içinde yer alan doğal varlıkların sömürüsü, bütünüyle siyasi denetim ve hesap sorulabilirlikten uzaklaştırılmış olur. ${ }^{49}$ Bireyler, kişisel tercihlerinin sisteme yansımasının en iyi yolunun iktisadi mekanizmalarla gerçekleşeceği düşüncesini benimsedikçe, politik alan işlevsizleşir. Serbest piyasa araçları artan bir biçimde siyasi araçlar olarak yorumlanırken, iktisadi alan siyasi alanı kendi bünyesine katarak siyasi

46 Ibid s. 118.

47 Friedrich Engels, Ailenin Özel Mülkiyetin ve Devletin Kökeni, Ankara, Sol Yayınları, 2012, s.201.

48 Bertell Ollman, Diyalektik Soruşturmalar, İstanbul, Yordam Kitap, 2011, s.46.

49 Ellen Meiksins Wood, Sermaye İmparatorluğu, İstanbul, Yordam Kitap, 2014, s.27- 28 
yapının içini boşaltır. Böylece iktisadi alan, bireylerin kendilerini ifade edebildikleri, ihtiyaçlarını dile getirip karşılayabildikleri ve nihayetinde politik alanın yerini tutan bir alan olarak görülmeye başlanır. ${ }^{50}$ Böylelikle ekolojik sorunlarla mücadele, sorunu yaratan aktörlerce finanse edilen sosyal sorumluluk projelerine dönüşmektedir. Büyümenin, sanayileşmenin ve hatta tüketimin çevre sorunlarının nedeni olmadığı, aksine tüm bunların ekolojik sorunları çözmede etkili araçlar olduğu fikri böylelikle haklılaştırılır. Toplumda ekolojik sorunlarla mücadele edildiği algısı yaratılsa da, aslında ekolojik mücadelenin serbest piyasanın işleyişini engellemesi önlenmektedir.

Marx’’n devleti "aldatıcı ortaklaşma" olarak tanımlaması, tam da bu özgürlük görüntüsünün yarattığı yanılsama nedeniyledir. Bu görüntü, bireylerin teker teker çıkarlarıyla toplumsal çıkarın uyum içinde olduğu imasını taşır. Oysa toplumsal çıkar olarak belirtilen, sermaye sınıfının çıkarından başka bir şey değildir. İş bölümü sonucu oluşan gruplaşmalar beraberinde farklı grup çıarlarını doğurur. Böylece toplumsal çıkarı artık var olamayacak şekilde yok ederek yerine farklı sınıfların farklı çıkarlarını yerleştirmiştir. Çatışan çıkarlardan biri, çıkarını gerçekleştirmek için daima diğeri üzerinde baskı kurmak durumundadır. İşte bu nedenle "aldatıcı ortaklaşma” tarafından toplumsal fayda için yapıldığı öne sürülen her bir edim, zorunlu olarak çatışan çıkarlardan yalnızca birini gözetmek zorundadır. ${ }^{51}$ Devletin tarafsız, yalnızca kendi varlığını dolayısıyla statükoyu sürdürmeye odaklı bir varlık olduğunu savunan görüş, devletin egemen sınıfın tarafında yer aldığına karşı çıksa da ${ }^{52}$, statükonun daima egemen sınıfın yararına olduğunu belirtmek gerekir. Sistemin devamını sağlamak, devletin egemen sınıfın çıkarlarına uygun hareket ettiğinin bir göstergesidir ve yukarıda değiniler görevleri arasında yer alır.

İktisadi sömürü biçimleri, yaşam alanlarının giderek daha fazla metalaştırılmasına, toplumsal ilişkilerin ise piyasanın yasalarıyla düzenlenmesine yol açar. Devletin tarafsızlığı yaklaşımı nedeniyle siyasi alanın giderek küçülmesi ve yerinin iktisadi alan tarafından doldurulması, ekolojik yıkımın yoğunlaşması, ezilen sınıfların yoksullaşması ve çeşitli ekolojik risklerle yüz yüze gelmesi süreçlerinde hesap verilebilirliği ortadan kaldırır. Siyasi alan bağımsız bir görüntü altında olsa da, yaşamın ve doğanın giderek artan bir biçimde iktisadi alana hapsolmasının aracı haline gelir. ${ }^{53} \mathrm{Bu}$ nedenlerle ekolojik mücadele aynı zamanda bir sınıf mücadelesidir ve sınıf mücadelesi ile ekolojik kriz birbirinden ayrı bir biçimde ele alınamaz ve çözümlenemez. ${ }^{54}$ Dolayısıyla ekolojik mücadelenin gerçek sorunu hedef alabilmesi, ekolojik kriz ile sınıf çatışması arasındaki ilişkinin ve devletin bu ilişkideki rolünün kavranmasıyla mümkündür.

\section{Sonuç}

Ekolojik kriz, sonuçları açısından hem toplumsal yaşam, hem de ekolojik dengenin sürdürülebilmesi için hayati bir risk oluşturmaktadır. Yaşanan kriz karşısında bugüne kadar devletin başarılı olamadığı ve sorunların günden güne daha ciddi boyutlara ulaştığı kabul edilmelidir. Toplum sözleşmesi

50 Eric Hobsbawm, Yeni Yüzyılın Eşiğinde, İstanbul, Yordam Kitap, 2011, s.127- 128.

51 Karl Marx ve Friedrich Engels, Alman İdeolojisi Fuerbach, Ankara, Sol Yayınları, 2013, s.58- 59.

52 T. Mitchell, "Limits of the State: Beyond Statist Approaches and Their Critics", The American Political Science Review, Cilt 85 No.1, 1991, s.94.

53 Wood, Sermaye Imparatorluğu, s.27- 28.

54 Burkett, Marx ve Doğa, s.264-265; Mary Mellor, “Socialism”, A. Dobson ve R. Eckersley (der.), Political Theory and the Ecological Challenge, New York, Cambridge University Press, 2006, s.35-50. 
kuramcılarının ileri sürdükleri gibi devlet, yurttaşlarına barış ve huzur ortamı sunma görevini yerine getirmeyi başaramamaktadır. Locke'un düşüncelerini geliştirerek ekolojik sorunların çözümüne uyarlayan eko-liberaller, sınırsız büyüme, sanayileşme ve aşırı tüketim gibi sorunlara neden olan temel etmenleri, krizin çözümüne yönelik reçeteler olarak sunmaktadır. Ancak yeryüzündeki doğal kaynaklar sınırlıdır ve üretim ile tüketimin tahrip ettiği doğal sistemler daha fazla büyümeyi kaldıramaz duruma gelmiştir. Sorunun çözülebilmesi için büyüme, sanayileşme ve tüketimin azaltılması gereklidir. Diğer taraftan ekolojik sorunları Hobbes'çu yaklaşımdan yola çıkarak değerlendiren eko-otoriteryanist görüş, demokratik uygulamaları ve katılımcıllğı dışlayarak, kontrol mekanizması olmayan güçlü bir yönetimi alternatif olarak sunmaktadır. Her iki yaklaşımın önerdiği devlet modeli günümüz ihtiyaçlarını karşılamaktan uzaktır.

Ekolojik kriz konusunda devlet gibi önemli bir aktörün konu dışına itilmesinin ne mantıklı ne de uygulanabilir olmadığını dile getiren yeşil devlet yaklaşımı ise, fonksiyon ve yönelimlerinde gerçekleştirilebilecek çeşitli dönüşümler yoluyla devletin daha yeşil bir hale gelebileceğini savunmaktadır. Oysa böylesi bir dönüşümün mümkün olup olmadığı, mümkün olsa bile ekolojik sorunların geri dönülemez boyutlara ulaşmadan gerçekleşip gerçekleşemeyeceği şüphelidir. Dahası, ekolojik sorunların boyutlarının ve taşıdığı risklerin günden güne artmasına karşın, yakın zamanda devletin temel fonksiyonlarında ekolojinin ekonomiyi önceleyeceğine yönelik herhangi bir işaret bulunmamaktadır.

Kapitalist sistemin doğal kaynakları bulundukları ekosistemlerden kopararak tekrar kullanılamaz atıklara dönüştürmesi, yeryüzünde kısıtlı miktarda bulunan maddelerin sürekli dolaşımına dayanan ekosistemlere çoğu zaman dönüşü olmayan şekilde zarar vermektedir. Kapitalist üretim biçiminin bireyi doğadan yalıtarak bireysel çıkarı önceleyen bakış açısı, ekolojik prensiplerle uyumlu değildir. Sürekli büyüme ihtiyacı, doğal varlıkların piyasa mekanizmasına dâhil edilmesini zorunu kılar. Doğal varlıklar, ekolojik döngüdeki işlevlerinden koparılarak piyasa çarkı içinde değişim değeriyle ifade edilen bir değere indirgenir. Bu süreçte bir taraftan yerel halkların temel kullanım mallarına ulaşımları sınırlanır ve eşitsizlik beslenirken diğer taraftan doğal döngüler üzerindeki baskı, kendi iç denetimleriyle kaldırabileceklerinin üzerine çıkar.

İktisadi alanın artan bir biçimde siyasi alanı kapsaması, ekolojik sorunlar karşısındaki mücadelenin yine iktisadi alanda gerçekleşmesine neden olmaktadır. Toplumda ekolojik sorunlarla mücadele edildiği algısı yaratılsa da, aslında ekolojik mücadelenin serbest piyasanın işleyişini engellemesi önlenmektedir. Bunun temel nedeni devletin yurttaşlar karşısında tarafsız bir konumda bulunmayışıdır. Tüm yurttaşlara eşit mesafede, taraf tutmayan ve yurttaşların haklarınıve özgürlüklerini koruyan bir devlet görüntüsü çizmesine karşın liberal devlet çıkar çatışmalarında kamu yararından yana karar almak yerine iktisadi faydayı gözeterek, egemen sınıfın yanında yer almaktadır. Devletin ekolojinin temel yasalarıyla uyumlu, ekonomik büyümeyi ekolojik ihtiyaçların önünde görmeyen ve kalkınmanın iktisadi olmayan boyutlarına odaklanabilen yeşil bir dönüşüme ihtiyacı vardır. Ancak böylesi bir dönüşüm ekolojik mücadele ile sınıf mücadelesinin bir arada yürütülmesiyle mümkündür. 